\title{
Optimization of electonics component placement design on PCB using genetic algorithm
}

\author{
Zinnatova L.I. \\ Kazan State Technical University named after A.N.Tupolev \\ KSTU named after A.N.Tupolev \\ Kazan, Russia \\ Lileka-leka@yandex.ru
}

\author{
Suzdalcev I.V. \\ Kazan State Technical University named after A.N.Tupolev \\ KSTU named after A.N.Tupolev \\ Kazan, Russia \\ iliasuzd@mail.ru
}

\begin{abstract}
This article presents modified genetic algorithm (GA) of the placement of electonic components (EC) on a printed circuit board (PCB) considering criterias of thermal conditions and minimum weighted sum.
\end{abstract}

Keywords- electronics component; printed circuit board; genetic algorithm; guillotine cutting; electronic device.

\section{INTRODUCTION}

The trend of most electronic companies is towards designing more functionality but smaller packages electronic system. Therefore, solving these problems requires using a large number of criteria and constraints with high dimension initial data.

The objective is to reduce the time, increase quality and lower the cost of design for the design of PCB using CAD systems. The best results of PCB designer was achieved by such companies as Altium Designer, Mentor Graphics, National Instruments, Zuken. These companies develop packages for designing $\mathrm{PCB}$, which have some advantages: large elements libraries, conversion of the files, inerrability of them in other CAD-systems, comfortable interface and etc. However, these systems have several disadvantages: the tasks consist only one criteria, ignore criteria of thermal conditions, in several systems there is also no automated placement of the EC on PCB.In this regard, there is a need to improve math and CAD software. The novelty of this work is to use the algorithm, for solving multi-criteria problem for placement EC on PCB.

\section{PROBLEM STATEMENT}

\section{A. The purpose of the work}

The purpose of the work is the development of a modified genetic algorithm of electronics component placement on a $\mathrm{PCB}$, considering criteria of thermal conditions and minimum weighted sum.

\section{B. Problem statement}

Statement of the placement problem is to find the location coordinates of EC placement on PCB with the predefined criteria and constraints.

\section{CRITERIA AND COONDITIONS FOR LOCATION PROBLEM}

A criterion of thermal conditions is proposed for placement of elements. Fitness function for this criteria can be expressed as:

$$
f_{t}=\sum_{i=1}^{N}\left|\sum_{\substack{j=1, j \neq i}}^{N}\left(P_{i}-P_{j}\right) d_{i j}\right| \rightarrow \min
$$

where $N$ is number of EC located on PCB; $P_{i}$ and $P_{j}$ are the thermal power dissipation $i$ and $j \mathrm{EC} ; d_{i j}$ - distance between $i$ and $j \mathrm{EC}$.

Using this criterion allows evenly distributing the EC on $\mathrm{PCB}$, which allows improving the quality of PCB.

Furthermore, it is proposed to take into account the criteria of minimum weighted sum. Fitness function for this criteria can be expressed as:

$$
f_{c}=\sum_{i=1}^{n} \sum_{j=0}^{n} c_{i j} d_{i j} \rightarrow \min
$$

where $c_{i j}$ - number of links between $i$ and $j E C$.

Using this criterion allows reducing the distance between the maximal connected EC, which simplifies the subsequent tracing and improves the electrical characteristics of the device.

\section{GENETIC ALGORITHM FOR PLACEMENT EC ON PCB}

A. Genetic algorithm

GA - is a search heuristic that mimics the process of natural evolution. 
Key terms for using GA:

- Individual is one potential solution.

- Population is a set of potential solutions.

- Chromosome is code representation of solutions. Gen is cell chromosomes, which can change its value.

- Allele is numeric value of gene.

- Locus is location of a gene in chromosome.

- Fitness function

- Generation - one cycle of the GA, including a procedure for breeding, mutation breeding [3].

B. Genetic algorithm for placement EC on PCB

Genetic algorithm using of the guillotine cutting of material. The plan of cutting is carried a binary tree.

The algorithm of placement EC on PCB using GA include next steps:

Step 0. Input of initial data.

Initial data of the problem are:

1. The number of the EC.

2. The number of links between $i$ and $j E C$.

3. The thermal power dissipation $i$ and $j \mathrm{EC}$.

4. The number of individuals in a population.

5. The number of generations of evolution.

Step 1. Creation of a new population. While creation of initial population a number individuals set at random. Each gene of chromosome gets its unique value.

Each solution is encoded by two chromosomes: XP1, XP2.

In contracts to the encoding of chromosomes proposed in articles [5], [6], we suggest another method of encoding chromosome XP1.

Chromosome XP1 contains coded information about the laying of the tree leaves, which indicate the order of the placement of EC on PCB: XP1 $=\{g l i \mid i=1,2, \ldots, n\}$. Each gene $g l i$ can take any value in the range $[1 ; n]$.

For example, $n=9$, XP1 (Fig.1): $<4,2,1,3,5,9,6,7,8>$.

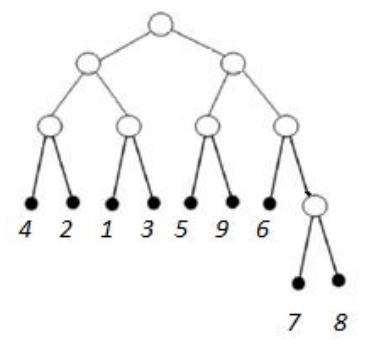

Fig.1. Binary tree for chromosome XP1
The proposed modification of the algorithm can significantly reduce the calculating time to solve the problem.

Chromosome XP2 contains coded information about the type of cut of PCB space.

Chromosome $X P 2=\{g 2 i \mid i=1,2, . ., n \bullet\}$ is the type of the cut (H or V).

The number of the gene XP2 is $n \bullet=n-1$.

The gene value is 0 or 1 , with $0-7$ corresponds to $V$ vertical cutting, and $1-\mathrm{H}-$ horizontal cutting.

For example:

Lets, $n=9, X P 2=<0,1,0,0,1,1,0,1>$ (Fig. 2).

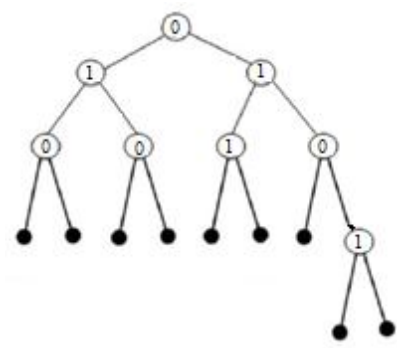

Fig. 2. Binary tree for chromosome XP2

Step 2. Crossover. All individuals of the population are formed in pairs at random. As soon as 2 solution-parents are selected, they are applied to a single-point crossover, which create two new solutions-offspring on their bases. Randomly selects one of the possible break point (Break point is the area between the adjacent bits in the string). Both parental structure are torn into two segments at this point. Then, segments of different parents stick together and produce two offsprings (Fig.3).

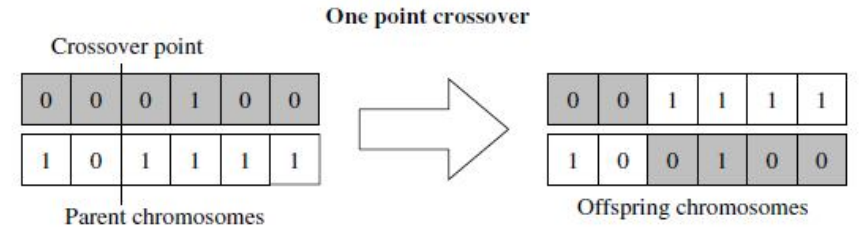

Fig.3. One point crossover

Step 3. Mutation. In case of mutations chromosomes undergoes some accidental modifications. In this work we propose using one-point mutation, where one bit in chromosome selects randomly and changes its value to the opposite one (Fig.4).

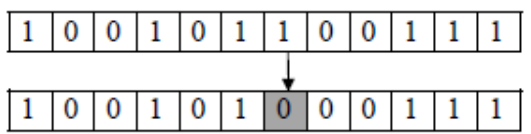


Fig.4. One-point mutation

Step 4. Designer of a binary tree cuts. Knowing the number EC, we can design the binary tree.

The total amount of EC $\left(E_{i}\right)$ - is the top of parent $\left(V_{0}\right)$. If $E_{i}$ is not equal 2 or $3, E_{i}$ will divide by 2 . The obtained values are rounded: the first figure in the smallest way, the second figure in the biggest way. The obtained tops (second level) are daughter vertex for $V_{0}$. The first figure will be the first daughter vertex $V_{1}$ for $V_{0}$, the second figure will be the second daughter vertex $V_{2}$ for $V_{0}$.

If the value of obtained daughter vertex $V_{1}$ and $V_{2}$ is not equal 2 or 3 , they are the top - parents, and they again might be halved. Halving will continue until all of the number of top-parents will be equal to two or three. With each subsequent level, the number of vertices will increase by $2^{k}$, where k - level (Fig.5).

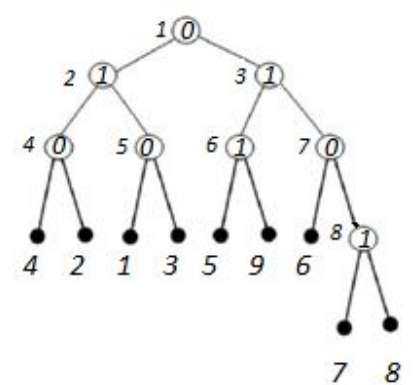

Fig.5. Binary tree cuts

When the number of top-parents is equal to 2, then topparent correspond to the two binary tree leaves (Fig.6).

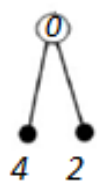

Fig.6. The example of the design binary tree cut

When number of top-parents is equal to 3, then top-parent corresponds to another top-parent, which owns two of the leaves and another binary tree leaf (Fig.7).

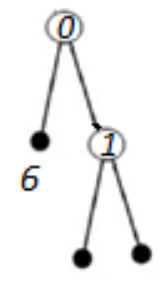

78
Fig.7. The example of the design of binary tree cut

Step 5. Binary convolution method. On the basis of this information, binary tree designer is carried out by means of serial binary convolution areas on the tree incisions, srarting with tree leaves. Each inner top of binary tree corresponds the area, obtained in the result of the binary convolution of a sub tree, with the root of the inner top. Consider that cut with number $i$ is cutting the top $d_{i}$ (area is $u_{i}$ ). In the beginning of convolution each top $d_{i}$, which is the leaf of the tree, is corresponding the area $s_{i}$ with dimension $x_{i}=a_{i}, y_{i}=b_{i}$, that is equal to module size $E_{i}$. For each inner vertex $d_{i}$ of tree corresponds the area $u_{i}$,which is formed by convolution subtree cuts, and has as its root vertex $d_{i}$.

Let's consider, that vertexes $d_{i}$ and $d_{j}$ are daughter vertex of $d_{k}$ and the areas $u_{i}$ и $u_{j}$ - corresponding $d_{i}$ and $d_{j}$ - are determined lower limits of their siz $\left(x, y_{i}\right),\left(x_{j}, y_{j}\right)$. The binary convolution is a fusion of areas $u_{i}$ and $u_{j}$, formation of $u_{k}$, dimensioning for $u_{k}$ and new sizes for $u_{i}$ and $u_{j}$. Let us introduce two infix operators $\mathrm{H}$ and $\mathrm{V}$.

The record $u_{k}=u_{i} H u_{j}$, means, that areas $u_{i}$ and $u_{j}$ merge horizontally in one area $u_{k}$. If $u_{k}=u_{i} B u_{j}$, then the areas $u_{i}$ and $u_{j}$ merge vertically.

Designate that $\max \left(x_{1}, x_{2}\right)$ is maximum value of $x_{1}$ and $x_{2}$.

At the confluence of the horizontal:

$$
\begin{aligned}
& y_{k}=\max \left(b_{i}, b_{j}\right) \\
& x_{k}=a_{i}+a_{j} \\
& y_{i} \text { and } y_{j} \text { will have the size equal } \max \left(b_{i}, b_{j}\right) .
\end{aligned}
$$

At the confluence of the vertical:

$$
\begin{aligned}
& y_{k}=b_{i}+b_{j} \\
& x_{k}=\max \left(a_{i}, a_{j}\right) ; \\
& x_{i} \text { and } x_{j} \text { will have the size } \max \left(a_{i}, a_{j}\right)
\end{aligned}
$$

For example:

The module dimensions $<4,2,1,3,5,9,6,7,8>$ are fixed. The area dimensions in accordance with the consistent convolution, will be defined as follows:

1. $u_{8}=7$ H ;

$$
\begin{aligned}
& y_{8}=b_{7}+b_{8} ; \\
& x_{8}=\max \left(a_{7} ; a_{8}\right) .
\end{aligned}
$$


2. $u_{7}=6 \mathrm{~V} u_{8}$

$$
\begin{aligned}
& y_{7}=\max \left(b_{6} ; y_{8}\right) ; \\
& \left.x_{7}=a_{6}+x_{8}\right) \text { and etc. }
\end{aligned}
$$
8.

The final plan of allocated modules is presented in figure

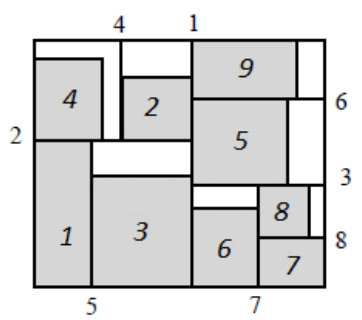

Fig. 8. The final plan of allocated modules

Step 6. Fitness function calculation.

Step 7. Selection. At each step of the evolution, individuals for next iteration are selected with the help of randomly selection operator. Selection allocates more copies of those solutions with higher fitness values and thus imposes the survival-of-the-fittest mechanism on the candidate solutions. The main idea of selection is to prefer better solutions to worse ones.

Step 8. The condition for the completion of the algorithm is the examination of the required number of iterations of the algorithm.

Step 9. Definition of the best individual (solution). The best solution of placement EC on PCB is the solution, which has the least result of fitness function.

Step 10. Result output.

\section{ACKNOWLEDGMENT}

To confirm the efficiency of the algorithm for placement EC on PCB using the genetic algorithm of guillotine cutting method a special software was developed.

The study of the efficiency was carried out.

Investigation №1. Test launches of the program with constant initial data and the change in the number of generations of evolution were carried out.

The source and resulting data are presented in table 1.
TABLE I.

\begin{tabular}{|c|c|c|c|}
\hline $\begin{array}{c}\text { The number } \\
\text { of the } \\
\text { placement EC }\end{array}$ & $\begin{array}{c}\text { The number } \\
\text { of individuals } \\
\text { in a } \\
\text { population }\end{array}$ & $\begin{array}{c}\text { The number } \\
\text { of generations } \\
\text { of evolution }\end{array}$ & $\boldsymbol{f}_{\mathrm{c}}$ \\
\hline 50 & 10 & 10 & 666985 \\
\hline 50 & 10 & 15 & 652074 \\
\hline 50 & 10 & 20 & 587125 \\
\hline 50 & 10 & 25 & 562158 \\
\hline 50 & 10 & 30 & 478745 \\
\hline 50 & 10 & 35 & 436585 \\
\hline 50 & 10 & 40 & 395781 \\
\hline 50 & 10 & 45 & 325641 \\
\hline 50 & 10 & 50 & 284578 \\
\hline 50 & 10 & 55 & 256485 \\
\hline 50 & 10 & 60 & 256484 \\
\hline 50 & 10 & 65 & 256484 \\
\hline 50 & 10 & 70 & 256484 \\
\hline
\end{tabular}

The table I is shown that with the increase of the generations of the evolution, the fitness-function decreases or remains unchanged, which testifies the optimal placement of the EC on the PP.

Investigation №2. Made a comparison of an iterative algorithm (IA) with our GA placement of EC on the PCB with the constant initial data.

TABLE II.

\begin{tabular}{|c|c|c|}
\hline $\begin{array}{c}\text { The number } \\
\text { of the } \\
\text { placement EC }\end{array}$ & $\boldsymbol{f}_{\mathrm{c}} \boldsymbol{G A}$ & $\boldsymbol{f}_{\mathrm{c}} \boldsymbol{I A}$ \\
\hline 10 & 5201 & 10257 \\
\hline 20 & 82114 & 320458 \\
\hline 30 & 157482 & 658921 \\
\hline 40 & 304580 & 845225 \\
\hline 50 & 478745 & 1036586 \\
\hline 60 & 658148 & 1203558 \\
\hline 70 & 851482 & 1698014 \\
\hline 80 & 1201425 & 2003688 \\
\hline 90 & 1582012 & 2365247 \\
\hline 100 & 1965214 & 2875218 \\
\hline
\end{tabular}

The table II is shown, that the values of the fitness-function GA is significantly less than the target function of iterative algorithm. Therefore, GA is more efficient than the standard algorithm.

\section{CONCLUSION}

In this paper proposed a developed software that implements automated procedures EC on PCB.

An important advantage of this software lies in the possibility taking into account the criteria of thermal conditions, while implementing the project the procedures, that will allow to increase the quality and reliability of the device. 
The developed software integrates CAD-system Mentor Graphics Expedition PCB, which significantly increases the ease of use for end users.

In the future, the developed software product will be applied on a number of enterprises of Tatarstan for the design and development of printed circuit boards: "Радиоприбор", "Electronics", etc.

\section{REFERENCES}

[1] Воронова B.B. Автоматизация проектирования электронных средств: Учебное пособие. Казань: Изд-во гос. техн. ун-та им. А..Туполева, 2000.-67 c/

[2] Родзин С.И. Гибридные интеллектуальные системы на основе алгоритмов эволюционного программирования // Новости искусственного интеллекта. 2000. №3. С. 159-170.

[3] Овчинников В.А., Васильев А.Н., Лебедев В.В. Проектирование печатных плат:Учебное пособие. 1-е изд. Тверь: ТГТУ, $2005.116 \mathrm{c.}$

[4] Лебедев Б.К., Лебедев В.Б., Адаптивная процедура выбора ориентации модулей при планировании СБИС// Известия ЮФУ. Технические науки. Тематический выпуск «Интеллектуальные САПР». - Таганрог: Изд-во ТТИ ЮФУ, 2010, № 7 (108). - 260 с.

[5] Лебедев Б.К., Лебедев В.Б., Планирование на основе роевого интеллекта и генетической эволюции// Известия ЮФУ. Технические науки. Тематический выпуск «Интеллектуальные САПР». - Таганрог: Изд-во ТТИ ЮФУ, 2009, № 4 (93). - 254 с. 